JMKSP (Jurnal Manajemen, Kepemimpinan, dan Supervisi Pendidikan)

Volume 7 Issue 1 (2022) Page 210-227

ISSN 2614-8021 (Online) 2548-7094 (Print)

\title{
Analysis of E-Module Development Needs on the Topic of Quantity and Units at High Schools in Payakumbuh
}

\section{Dinda Wulandari ${ }^{1}$, Eko Risdianto ${ }^{1}$, Fitri Masito ${ }^{2}$, Iwan Setiawan ${ }^{1}$, Rusdi Efendi ${ }^{1}$ \\ ${ }^{1}$ Universitas Bengkulu, ${ }^{2}$ Politeknik Penerbangan Palembang Corresponding Author E-mail: dindhaw64@gmail.com}

Received 24 May 2021; Revised 28 September 2021; Accepted 26 January 2022

\begin{abstract}
This study has the aim of analyzing the responses of physics teachers and students to the need for developing e-modules on the amount and units of material at the SMA Negeri in Payakumbuh City. This research is part of the R \& $D$ research with the ADDIE model but is only limited to the needs analysis stage using quantitative methods. The sampling technique used was purposive sampling with data samples, namely 8 physics teachers and 250 students in 5 high schools during the covid-19 pandemic. Data collection techniques used are interviews, questionnaires and observation. The instrument used is a questionnaire on the need for e-module development for physics students and teachers. The results of this study indicate that the instruments used are valid and reliable and show that physics teachers and students strongly agree that the e-module material on quantities and units really needs to be developed to support effective online learning. Different from previous research, the update of this research was carried out in all public high schools in Payakumbuh City and focused on physics subject matter of quantities and units. This research contributes to educational practitioners so that they can develop an e-module teaching material product of magnitude and unit material for students.
\end{abstract}

Keyword: Pandemic, Learning Media, E-Modul 


\section{Introduction}

The changes that are happening today are facing the digital era 4.0 (Wening $\&$ Santosa, 2020). The very rapid development of technology today is no longer a continuation for the third industrial revolution, but as a gateway for the arrival of the industrial revolution 4.0 or industry 4.0. Industry 4.0 is a cyber-physical system which means that technology is no longer a tool but embedded in the lives of citizens. For the current era in the industrial revolution 4.0, technology has become a necessity, especially in education, it cannot be denied anymore (Reflianto \& Syamsuar, 2018). The disruption to innovation has resulted in Education 4.0 which focuses on developing learning and skills, making future education more customized, hyper, smart, portable, worldwide and virtual (Shahroom \& Hussin, 2018). The future and the current generation will depend on how we prepare for these challenges ahead of time, and how we can mitigate the threats that come (Rymarczyk, 2020).

The COVID-19 pandemic is a major challenge for the education system (Daniel, 2020). In early 2020, several cases of the novel coronavirus, 2019-nCoV appeared across China (Sen et al., 2021). As if not wanting to stop, the virus outbreak known as the Covid-19 virus is still mushrooming everywhere in almost all countries. Therefore, to reduce the development of Covid-19, relying on the source of the message disseminated by the Minister of Learning and Culture regarding the Emergency Period for the Spread of COVID-19 in carrying out the Education Policy, which said that schools and learning were tried from home through the online / distance education process described in circular message No. 4 of 2020. In Indonesia, in August 2021, we are still carrying out online learning during the covid-19 pandemic (Mi et al., 2021).

This matter greatly affects the implementation of education at all levels of education starting from elementary school to university. The need for learning motivation for students is needed as a support for learning success. So that in this pandemic condition, implementation is needed to support education as well as to encourage student learning. As the nature of learning motivation is an internal and external encouragement for students who are learning to make changes in behavior, usually with some supporting markers or factors. This matter has a great meaning in increasing one's progress in learning (Ompusunggu, 2020).

Students regard physics as a difficult subject during their high school days and are somewhat evasive when they reach college (Guido, 2018). Physics module is a subject that must be studied in high school (SMA). Most of the 
students' alibis do not like physics lessons because there are so many formulas that must be memorized and the atmosphere of learning physics seems very saturated and monotonous. Not only that, students also lack mastery of physical symbols from the information mentioned in the questions, and students do not recheck the answers that have been written. So the fact is that physics is considered difficult and disliked by most students (Agustin et al., 2019).

What do we want teaching materials for? Teaching materials are one of the important needs and must be met in the learning process. Researchers found some of the problems were the use of teaching materials that were less varied in education and the limited number of photos in textbooks so that students were less enthusiastic in the educational process. So we need teaching materials that can attract the attention of students (Kholipah et al., 2020). Learning can be done effectively if teaching materials support learning activities (Hartini et al., 2018). A minimum of teaching materials includes, among others: 1. Information on the use of teaching materials (use for students/educators) 2. Competencies to be achieved 3. Additional information 4. Assignments 5. Work instructions, can be in the form of worksheets 6. Evaluation (Zainul, Adha., Gusnaedi., Letmi, 2018). 1989, Chapter 1, Article 1 is an effort to come to plan students through the movement of guidance, teaching, or training for their role in the future (Juliansari et al., 2020).

One of the materials in physics learning is quantity and unit. Quantities and units are one of the most basic physics subject matter (Widiyatun et al., 2020). This material has a lot to do with the life in the environment that students feel. In addition, teachers often use student worksheets whose structure and content are still monotonous, namely the concept of material is lacking and the practice questions are too difficult. In addition, the material for quantities and units of Physics is the starting material for class $\mathrm{X}$ students in the physics learning process, therefore it is necessary to make interesting and systematic teaching materials so that students feel interested and happy to pursue Physics..

Using ICT in learning can optimize lifelong learning through remote and asynchronous modes (Sethy, 2012). The growth of technology, information and communication also affects the progress of innovation in teaching materials. Innovations from the development of teaching materials include electronic modules (e-modules). E-Modules are reading materials in the form of soft files that can be opened and read anywhere and anytime by students. With the development of teaching materials in the form of e-modules, it is expected to be able to reduce boredom and increase students' interest and learning outcomes in 
learning physics (Andani \& Yulian, 2018). Therefore, electronic modules (emodules) are a good development choice because conventional ones (print modules) are less interactive and have a static or monotonous image display while e-modules can interactively present material presented by multimedia such as videos, animations, simulations., and questions with immediate feedback (Irwansyah et al., 2017). In addition, the module must also have a context that touches students' lives, so that the use of the module is more touching, and can be directly applied to the community (Verawati et al., 2020).

Interest is a psychological aspect that can affect learning activities (Dewantari $\&$ Singgih, 2020). Interest can affect the quality of learning outcomes. This shows that a teacher has a relationship in increasing student learning interest in mastering the material by implementing a method of developing teaching materials that can attract students' learning attention. Students' learning attention will affect the learning of physics at school. It can be seen from the teachers who are still practicing the lecture method which is supported by textbooks provided by the government. The textbook used only covers information universally so that students find it difficult to relate it to the area around their living environment. However, it is necessary to learn from real life, so that science can contribute in practice (Gunawan, 2021). Therefore, educators need to design learning activities and character development of students that are interesting, meaningful, motivating and effective (Primasari et al., 2019).

Generation $\mathrm{Z}$ is gaining popularity as a name used to refer to those born from the mid to late 1990s (Moore et al., 2017). This generation will enter the company in the years to come but little is known about their characteristics, needs, attributes and work styles. The development of technology at this time is increasingly sophisticated so that it can affect the teaching and learning process, both in media, teaching aids, learning resources or others. This matter greatly affects the position of principals and teachers who are reliable in preparing generation $\mathrm{Z}$ students, starting from the position of the principal as an educator, teacher, administration, supervisor as well as the expertise to develop teachers, the expertise to explore growth in the field of education, and teachers in the ability of learning materials., expertise in using multiple learning methods for the best solution to improve the quality of education through schools. Therefore, students prefer to learn visually and digitally, and educators should be able to develop more interesting teaching materials (Fitriyani, 2018). 
As the results of observations made by researchers in five public high schools in Payakumbuh City, West Sumatra Province, in August the odd semester of the 2021/2022 questionnaire year through interviews and observations with physics teachers and class X Mathematics and Natural Sciences researchers, obtained information that high schools in Payakumbuh City in general online learning is applied during this Covid-19 pandemic. Learning is done through the help of the whatsapp group application and google classroom. Constraints in the form of an inadequate network make online learning unable to be done face-to-face virtual through zoom meetings, google meetings, or other virtual face-to-face applications. Based on interviews with teachers and several students as well as observations, during the Covid-19 pandemic, physics learning carried out in schools was not optimal. learning activities are only in the form of assignments and theory delivery. Physics practicum activities have never been carried out during daring learning. This makes physics a boring subject, feared and considered difficult by most students in class X MIPA at the school and the teaching materials distributed by the teacher are less attractive.

Relevant research includes research by Fitrianingsih et al., (2021) with the results of the analysis showing that students stated that the Islamic integrated emodule can help in understanding physics learning materials, especially energy materials. In addition, the research of Yuliawati et al., (2021) with the results showing the analysis of research data from the needs analysis of the adobe flashbased e-module learning media, it was found that the results of the questionnaire distribution showed that students needed adobe flash-based e-module learning media because of difficulties in learning. receive material.

Therefore, researchers conducted this study to find out the description of emodule teaching materials focused on physics subjects, namely the material of quantities and units, considering that physics is an important science learning and it cannot be denied that physics is considered a difficult subject matter for most high school students. Therefore, this study focuses on analyzing the needs for developing e-modules of materials and units at the Payakumbuh High School level. Different from previous research, the update of this research was carried out in all public high schools in Payakumbuh City and focused on physics subject matter of quantities and units.

Thus, based on the description above, research is needed to create appropriate teaching materials so that they can guide students in mastering concepts about physics, especially in the material of optimal quantities and units. Student learning 
resources are in the form of teaching materials that can increase the interest and learning outcomes of high school students in class X MIPA (Mathematics and Natural Sciences). This study aims to identify the needs needed in the field before the preparation of the e-module material of magnitude and units at the Payakumbuh City High School level, then an analysis of the need for the development of the Payakumbuh City High School level material is analyzed in accordance with the demands of the 2013 curriculum and the characteristics the material presented. Before deciding to make the development of e-modules, researchers must first analyze the students' needs for the development of learning modules as alternative teaching materials that can be used later. Based on the explanation above, this research has a problem formulation, namely, is it necessary to analyze the need for the development of e-module modules of magnitude and units at the high school level in Payakumbuh City?. So based on the formulation of the problem, the purpose of this study is to analyze the needs of the e-module material of magnitude and unit at the high school level in Payakumbuh City.

\section{Methods}

This research uses development research procedures with addie models with several tapahan namely Analysis, Design, Development \&Implementation, and Evaluation. Research is limited to the analysis stage. Analysis is the beginning in the process of developing and analyzing needs, analyzing the curriculum, and analyzing the material is the way to do it. In the stage of needs analysis is done by making observations, interviews and questionnaires to find out the use of learning media at the time of learning. This research is located in the state high school of Payakumbuh City as many as 5 schools. Research time in August odd semester of school year 2021/2022. The population is a generalization area that is composed of objects or subjects that have certain quantities and characteristics that are authorized by research to be studied and after that can make conclusions (Sinaga, 2020). The population of this study was taken from physics teachers who taught in class X MIPA and students of class X MIPA at Payakumbuh City State High School with the number of learners, namely 250 learners and 8 physics teachers. While the sample is the total addition and characteristics consisting of the population itself (Ilham et al., 2021). In taking this sample, the researcher used purposive sampling. This technique is used if the sampling technique is based on certain considerations. In this study using data collection techniques in the form of 
questionnaire techniques, observation techniques and interview techniques. The observation sheet is the instrument used in this study, the questionnaire sheet analyzing the needs of teachers and students presented in google form as well as literature related to the development of e-module material of magnitude and unit at the Payakumbuh High School level. Needs questionnaire analysis was obtained using a modified Likert scale. This study uses a Likert scale in the form of four responses as shown in table 1 below.

Table 1 Likert Scale for Rating

\begin{tabular}{ccc}
\hline No & Alternative Answer & Score Weight \\
\hline 1 & Strongly agree & 4 \\
2 & Agree & 3 \\
3 & Do not agree & 2 \\
4 & Strongly Disagree & 1 \\
\hline
\end{tabular}

(Liana et al., 2019)

The rule of decision the item is said to be valid if rcount is greater than the value of rtable ( $r_{\text {count }}>r_{\text {table }}$ ) and is said to be invalid if rcount is less than the value of rtable $\left(r_{\text {count }}<r_{\text {table }}\right)$ (Budiwibowo \& Nurhalim, 2016).

Next, calculate the percentage of each question/statement using the following equation.

Percentage of each question $=\frac{\text { earn scale }}{\max \text { scale }} \times 100 \%$

After trying the calculation on each question/statement, the average value of the percentage is sought by adding up the percentage of each question after that divided by the number of respondents and the result is called the percentage of average value. After that, try to match the results of the calculation of the average value with the evaluation criteria listed in table 2.

Table 2 Criteria for Assessment of Needs Analysis Questionnaire Sheet

\begin{tabular}{cc}
\hline Percentage $(\boldsymbol{\%})$ & Category \\
\hline $0 \%-25 \%$ & Strongly Disagree \\
$26 \%-50 \%$ & Do not agree \\
$51 \%-75 \%$ & Agree \\
$76 \%-100 \%$ & Strongly agree \\
\hline
\end{tabular}

(Sari et al., 2020) 


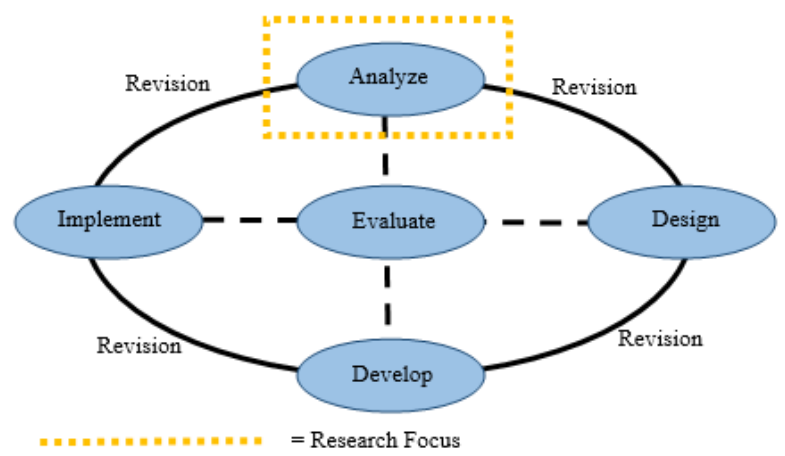

Figure 1 ADDIE Model Development Design

ADDIE Model (Analysis, Design, Development, Implementation, Evaluation). These five stages are a guide for the minister to find effective learning and get optimal results. Almost all classic models of instructional design are variations of the ADDIE model. The following explanations of the ADDIE model are: (1) The Analysis Phase includes: needs assessment. (2) The design phase (design phase) includes the development of objectives, test items, and learning strategies. (3) the stage of development, which includes the preparation of teaching materials. (4) The implementation phase includes activities to support the delivery of instructions. (5) The evaluation phase includes formative and summative evaluation. They are schematically illustrated in Figure 1 (Winaryati \& Munsarif, 2021).

\section{Results and Discussion}

The needs analysis refers to the situation in the school, namely the State Senior High School in Payakumbuh City, which consists of 5 schools. This analysis is needed to identify whether the e-module media really needs to be developed or not. The needs analysis in this research is based on observations in schools when providing instruments in the form of a questionnaire, analyzing the needs of physics teachers with a total of 8 people and 250 students presented in google form, distributing observation sheets filled out by the principal or his representative, direct interviews with 8 physics teachers and indirect interviews with 45 students. The distribution of questionnaires presented via google forms to students and teachers to determine whether students want to learn to use electronic teaching materials or not supported by observation sheets and interview sheets. The evaluation of the answers to the questionnaire used a modified Likert scale 
with the highest score of 4 and the lowest 1 . Each item of the problem used in the questionnaire was tested for validity and reliability to find out whether the instrument was suitable for use and indeed needed to be developed or not. The results stated that the items in the instrument were valid and reliable. In more detail can be seen in table 3-8.

Tabel 3. Teachers Validity Test Results

\begin{tabular}{cccc}
\hline $\begin{array}{c}\text { Number } \\
\text { of Items }\end{array}$ & r-Calculate & r-Table & Description \\
\hline 1 & 0,769079 & 0,706734 & Valid \\
2 & 0,769079 & 0,706734 & Valid \\
3 & 0,720437 & 0,706734 & Valid \\
4 & 0,851114 & 0,706734 & Valid \\
5 & 0,933304 & 0,706734 & Valid \\
6 & 0,933304 & 0,706734 & Valid \\
7 & 0,933304 & 0,706734 & Valid \\
8 & 0,851114 & 0,706734 & Valid \\
9 & 0,933304 & 0,706734 & Valid \\
10 & 0,748969 & 0,706734 & Valid \\
11 & 0,851114 & 0,706734 & Valid \\
12 & 0,933304 & 0,706734 & Valid \\
13 & 0,933304 & 0,706734 & Valid \\
14 & 0,933304 & 0,706734 & Valid \\
15 & 0,851114 & 0,706734 & Valid \\
16 & 0,825462 & 0,706734 & Valid \\
17 & 0,933304 & 0,706734 & Valid \\
18 & 0,851114 & 0,706734 & Valid \\
19 & 0,933304 & 0,706734 & Valid \\
20 & 0,825462 & 0,706734 & Valid \\
21 & 0,851114 & 0,706734 & Valid \\
22 & 0,825462 & 0,706734 & Valid \\
23 & 0,825462 & 0,706734 & Valid \\
24 & 0,825462 & 0,706734 & Valid \\
25 & 0,933304 & 0,706734 & Valid \\
26 & 0,825462 & 0,706734 & Valid \\
27 & 0,825462 & 0,706734 & Valid \\
28 & 0,825462 & 0,706734 & Valid \\
29 & 0,933304 & 0,706734 & Valid \\
30 & 0,825462 & 0,706734 & Valid \\
\hline
\end{tabular}


In table 3, it can be seen that all the questionnaire items for the teacher needs analysis have a t-count value greater than t-table, which means that all items in the questionnaire are valid.

Tabel 4. Students Validity Test Results

\begin{tabular}{|c|c|c|c|}
\hline $\begin{array}{l}\text { Number } \\
\text { of Items }\end{array}$ & r-Calculate & r-Table & Description \\
\hline 1 & 0,445712 & 0,124101 & Valid \\
\hline 2 & 0,325301 & 0,124101 & Valid \\
\hline 3 & 0,238542 & 0,124101 & Valid \\
\hline 4 & 0,131134 & 0,124101 & Valid \\
\hline 5 & 0,155267 & 0,124101 & Valid \\
\hline 6 & 0,38154 & 0,124101 & Valid \\
\hline 7 & 0,617407 & 0,124101 & Valid \\
\hline 8 & 0,618317 & 0,124101 & Valid \\
\hline 9 & 0,52265 & 0,124101 & Valid \\
\hline 10 & 0,594117 & 0,124101 & Valid \\
\hline 11 & 0,586118 & 0,124101 & Valid \\
\hline 12 & 0,53818 & 0,124101 & Valid \\
\hline 13 & 0,607272 & 0,124101 & Valid \\
\hline 14 & 0,613921 & 0,124101 & Valid \\
\hline 15 & 0,68305 & 0,124101 & Valid \\
\hline 16 & 0,543955 & 0,124101 & Valid \\
\hline 17 & 0,489873 & 0,124101 & Valid \\
\hline 18 & 0,665103 & 0,124101 & Valid \\
\hline 19 & 0,70846 & 0,124101 & Valid \\
\hline 20 & 0,685373 & 0,124101 & Valid \\
\hline 21 & 0,576591 & 0,124101 & Valid \\
\hline 22 & 0,556347 & 0,124101 & Valid \\
\hline 23 & 0,62607 & 0,124101 & Valid \\
\hline 24 & 0,640459 & 0,124101 & Valid \\
\hline 25 & 0,707499 & 0,124101 & Valid \\
\hline 26 & 0,675849 & 0,124101 & Valid \\
\hline 27 & 0,707181 & 0,124101 & Valid \\
\hline 28 & 0,685239 & 0,124101 & Valid \\
\hline 29 & 0,656763 & 0,124101 & Valid \\
\hline 30 & 0,635227 & 0,124101 & Valid \\
\hline
\end{tabular}

In table 4 it can be seen that all the items of the student needs analysis questionnaire have a t-count value greater than $\mathrm{t}$-table, which means that all items in the questionnaire are valid. 
In table 5 it can be seen the results of the validity test for the needs analysis questionnaire for physics teachers who teach in class X Mathematics and Natural Sciences.

Table 5 Case Processing Summary

\begin{tabular}{|c|c|c|c|}
\hline & & $\mathrm{N}$ & $\%$ \\
\hline \multirow{3}{*}{ Cases } & Valid & 8 & 100,0 \\
\hline & Excluded $^{\mathrm{a}}$ & 0 & 0,0 \\
\hline & Total & 8 & 100,0 \\
\hline
\end{tabular}

Table 6. Reliability Statistics

\begin{tabular}{c|c}
\hline Cronbach's Alpha & N of Items \\
\hline 0,987 & 30 \\
\hline
\end{tabular}

In the summary table for processing teacher needs analysis questionnaires, it appears that there are 30 valid questions $(\mathrm{N})$. There is no information excluded (Excluded). A total of 8 information $(\mathrm{N})$ was processed or $100 \%$ of the information was processed. In table 6 the reliability statistics show the results of the calculation of the reliability of information using the Cronbach's alpha method with a score of 0.987 . The value obtained (0.987) is compared with the value of the product moment $r$ table. The distribution of $r$ table used is $\alpha=0.05$, the value is 0.707, after that it is compared with Cronbach's alpha value of 0.987 . sourced from the decision rules of research methods in research procedures it is decided that the alpha value is $0.987>0.707$, from this information it can be said that the data obtained is very reliable.

In table 7 it can be seen the results of the validity test of the student needs analysis questionnaire.

Table 7. Case Processing Summary

\begin{tabular}{l|l|r|r}
\hline \multicolumn{2}{l|}{} & N & \multicolumn{1}{c}{$\%$} \\
\hline Cases & Valid & 250 & 100,0 \\
& Excluded $^{\mathrm{a}}$ & 0 & 0,0 \\
& Total & 250 & 100,0 \\
\hline
\end{tabular}

Table 8. Reliability Statistics

\begin{tabular}{c|c}
\hline Cronbach's Alpha & N of Items \\
\hline 0,917 & 30 \\
\hline
\end{tabular}

In the summary table of problem processing for teacher needs analysis questionnaires, it appears that there are 30 valid questions $(\mathrm{N})$. There is no information excluded (Excluded). A total of 250 information $(\mathrm{N})$ was processed or $100 \%$ of the information was processed. In table 8 the reliability statistics show the results of the calculation of the reliability of the information using the Cronbach's alpha procedure with a score of 0.917 . The value obtained (0.917) is 
compared with the value of the product moment $r$ table. The distribution of $r$ table used is $\alpha=0.05$, with a value of 0.124 , after that it is compared with Cronbach's alpha value of 0.917. sourced from the rules of decision making in the research method it was decided that the alpha value was $0.917>0.124$, so that the information could be said to be very reliable.

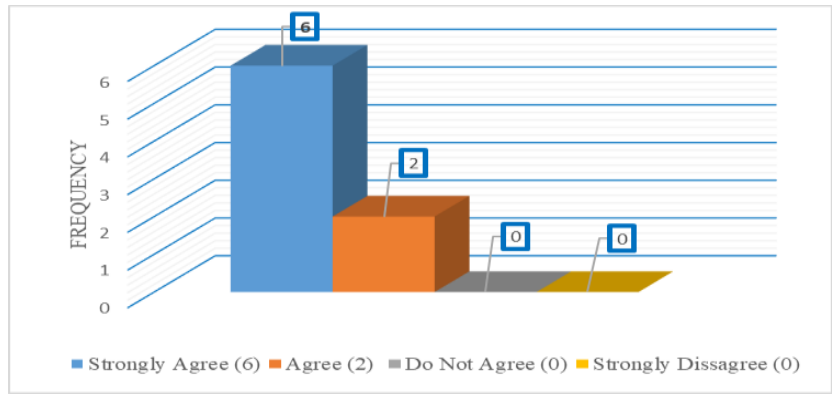

Figure 2 Physics Teacher Data

From the information in Figure 2, it is found that 8 physics teachers in five Payakumbuh schools who filled out a physics teacher needs analysis questionnaire there were 6 physics teachers in the category strongly agree, 2 physics teachers in the agree category, 0 physics teachers in the disagree category and 0 physics teachers in the category strongly disagree. It can be concluded that physics teachers or educators strongly agree that e-module media does need to be developed.

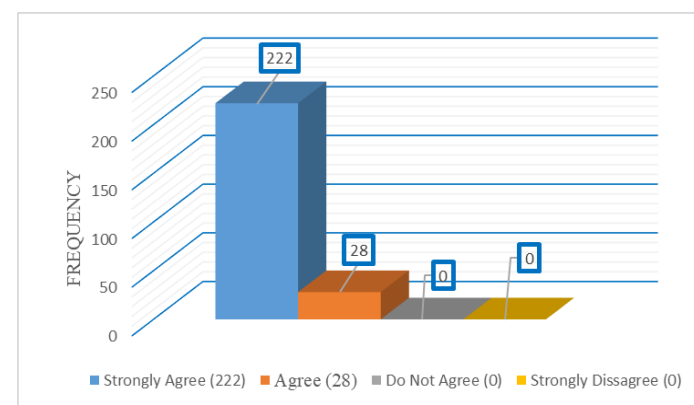

Figure 3 Student Data

Based on the information from Figure 3, the results obtained from 225 students in five Payakumbuh High Schools who filled out a student needs analysis questionnaire there were 222 students in the category of strongly agree, 28 
students in the agree category, 0 students in the category of disagree and 0 students in the category of strongly disagree. It can be concluded that students and physics teachers or high school educators in Payakumbuh City strongly agree that e-module learning media does need to be developed..

Next use the percentage formulae $\mathrm{P}=\frac{n}{N} \times 100 \%$ to determine the percentage of student and physics teacher responses to the need for e-module development of material quantities and units at the high school level in Payakumbuh City.

Table 9. Results of Physics Teacher Response Data to the Need for E-modules

\begin{tabular}{ccccc}
\hline Respondent & Total Score $(\mathrm{n})$ & $\begin{array}{c}\text { Max Score } \\
(\mathrm{N})\end{array}$ & Percentage & Category \\
\hline $\begin{array}{c}\text { 8 High School Physics } \\
\text { Teacher }\end{array}$ & 860 & 960 & $89,60 \%$ & Strongly agree \\
\hline
\end{tabular}

Based on the information from table 9, it is found that the percentage of physics teacher responses to the need for e-module development of material quantities and units at the high school level in Payakumbuh City is $89.60 \%$ of the maximum percentage of $100 \%$. In accordance with the Likert scale interpretation table for data with a percentage of $76 \%-100 \%$ categorized as very good or strongly agree.

Table 10. Results of Student Response Data on E-module Needs

\begin{tabular}{ccccc}
\hline Respondent & Total Score $(\mathrm{n})$ & $\begin{array}{c}\text { Max Score } \\
(\mathrm{N})\end{array}$ & Percentage & Category \\
\hline 250 High School Students & 25390 & 30000 & $84,60 \%$ & Strongly agree \\
\hline
\end{tabular}

Meanwhile, based on information from table 10 , it is found that the percentage of student responses to the need for developing e-modules of materials and units at the high school level in Payakumbuh City is $84.60 \%$ of the maximum percentage of $100 \%$. The same as the percentage of teacher responses according to the Likert scale interpretation table for data with a percentage of $76 \%-100 \%$ categorized as strongly agree. In accordance with the Likert scale interpretation table for data with a percentage of $76 \%-100 \%$ categorized as very good or strongly agree.

In addition to using questionnaire data to analyze the needs of teachers and students, the researchers also conducted a literature study on previous research related to the research topic, some of the literature studied were as follows: 1). Research attempted by (Fitrianingsih et al., 2021) entitled "Needs Analysis of Islamic Integrated Science Electronic Module (E-Module) Development" in this 
study was only carried out at the define (definition) stage. The results of the questionnaire collection can be concluded that students who do not recognize the module can help serve as a benchmark for learning resources there are $74 \%$ of students. and as many as $89 \%$ of students stated that the development of emodules can help in understanding physics learning materials, especially energy materials. 2). After that the research attempted by (Utami \& Yuwaningsih, 2020) the journal entitled "E-Module Development Needs Analysis on Derivative Subjects Using Kvisoft Flipbook Maker Pro for Class XI High School Students". The results of the study show the results, namely (1) the teaching materials needed by students are innovative teaching materials in the form of e-modules; (2) emodules are not only presented in writing but can be added to videos and animations so that students do not get bored easily during the learning process. 3 ). Then the research conducted by (Huda, 2019) the journal entitled "Learning Effectiveness with Contextual Teaching Learning (CTL) Models to Improve Physics Learning Outcomes in Class X on the Concept of Quantity and Measurement" obtained data on classical experimental class learning completeness of $81.8 \%>$ from classical control class completeness which was only equal to $42.8 \%$. Based on the research that has been done previously, it is necessary to do similar research with the application of the subject in other topics and further development as well as the existence of innovation and creativity in creating the development of e-module material of magnitude and unit at the high school level in Payakumbuh. The advantages obtained from the research entitled "Analysis of the Need for Development of E-module Material Quantities and Units at the Payakumbuh high school level" are that it can be further developed by subsequent researchers to create an interactive e-module teaching material product, one example of an online module is that students can access the link that has been provided when the detailed material in the e-module does not exist so that students can get detailed information on the material that has not been included in the e-module teaching material by visiting the link. Meanwhile, offline use, students only get information from e-module books that have been made by the maker.

\section{Conclusion}

Based on the results of research through interview data collection techniques, questionnaires and observations conducted at the payakumbuh city high school level and the above discussion was concluded that the results of the analysis of 
the needs of the development of e-modules of materials and units at the high school level of Payakumbuh City showed that students and physics teachers strongly agree that the medium of learning e-modules of materials and units does need to be developed to support effective learning during online. The results of this study also showed that the instruments used were valid and reliable. It can be concluded that the data obtained is reliable. Other information obtained states that electronic-based teaching materials as a learning medium have not been optimally developed in schools. Teaching materials such as electronic-based modules need to be developed again because students learn not always using teaching materials in the usual especially in the time of the covid-19 pandemic, it is expected that by using teaching materials that foster interest in learning such as electronic modules, students can change their opinions and thoughts that physics is a difficult but fun subject.

\section{Acknowledgement}

The authors would like to thank the participants, teachers and high school principals in Payakumbuh City who supported the study. Thank you also spoken to the Physics Education Study Program of the Faculty of Teacher Training and Education (FKIP) of The University of Bengkulu who has given permission to the author to participate in the Merdeka Belajar Kampu Merdeka (MBKM) research program, where this article is one of its outputs and so on to all parties who greatly contribute and support in helping to collect data and in testing this research. Thank you to the JMKSP team (Journal of Management, Leadership, and Education Supervision) who have provided input in the peer review process.

\section{References}

Agustin, M., Maryani, M., \& Supriadi, B. (2019). Pengaruh Model Pembelajaran Kooperatif Tipe Think Talk Write Dengan Metode Talking Stick Terhadap Aktivitas Dan Hasil Belajar Fisika Siswa SMA [The Influence of the Think Talk Write Cooperative Learning Model With the Talking Stick Method on the Activities and Learning Outcomes of High School Students in Physics]. FKIP E-Proceeding, 4(1), 191-194. Retrieved from https://jurnal.unej.ac.id/index.php/fkipepro/article/view/15165

Andani, D. T., \& Yulian, M. (2018). Pengembangan Bahan Ajar Electronic Book Menggunakan Software Kvisoft Flipbook Pada Materi Hukum Dasar Kimia di SMA Negeri 1 Panton Reu Aceh Barat [Development of Electronic Book Teaching 
Materials Using Kvisoft Flipbook Software on Chemical Basic Law Materials at SMA Negeri 1 Panton Reu Aceh Barat]. Jurnal IPA \& Pembelajaran IPA, 2(1), $1-$ 6. https://doi.org/10.24815/jipi.v2i1.10730

Budiwibowo, A. K., \& Nurhalim, K. (2016). Pengaruh Motivasi Belajar Terhadap Prestasi Belajar Warga Belajar Kejar Paket C. Journal of Nonformal Education, 2(2), 168-174.

Daniel, S. J. (2020). Education and the COVID-19 pandemic. Prospects, 49(1-2), 91-96. https://doi.org/10.1007/s11125-020-09464-3

Dewantari, N., \& Singgih, S. (2020). Indonesian Journal of Natural Science Education (IJNSE). Indonesian Journal of Natural Science Education (IJNSE), 03(2), 366371.

Fitrianingsih, D., Aulianingsih, I., \& Yuliani, H. (2021). Analisis Kebutuhan Pengembangan Modul Elektronik (E-Module) IPA Terintegrasi Islam [Needs Analysis of Islamic Integrated Science Electronic Module (E-Module) Development]. Jurnal Ilmiah Pendidikan Fisika, 5(1), 27. https://doi.org/10.20527/jipf.v5i1.2525

Fitriyani, P. (2018). Pendidikan Karakter Bagi Generasi Z [Character Education for Generation Z]. Knappptma, 7(Maret), 307-314.

Guido, R. M. D. (2018). Attitude and Motivation towards Learning Physics. 2(11), 20872094.

Gunawan, R. (2021). Rudy Gunawan 4 1,2,3. 6(2), 181-199.

Hartini, S., Firdausi, S., Misbah, \& Sulaeman, N. F. (2018). The development of physics teaching materials based on local wisdom to train Saraba Kawa characters. Jurnal Pendidikan IPA Indonesia, 7(2), 130-137. https://doi.org/10.15294/jpii.v7i2.14249

Huda, S., \& Sumiati, A. (2019). Pengaruh PAD, DAU, dan dak Terhadap Belanja Modal Pemerintah Daerah [Influence of PAD, DAU, and not on Regional Government Capital Expenditure]. Jurnal Ilmiah Wahana Akuntansi, 14(1), 85-100. https://doi.org/10.21009/wahana.14.016

Ilham, D., Sunarsi, D., Suryakancana, U., \& Barat, J. (2021). Manajemen Sumber Daya Manusia [Human Resource Management]. Jurnal Ilmiah, 4(3), 332-346.

Irwansyah, F. S., Lubab, I., Farida, I., \& Ramdhani, M. A. (2017). Designing Interactive Electronic Module in Chemistry Lessons. Journal of Physics: Conference Series, 895(1). https://doi.org/10.1088/1742-6596/895/1/012009

Juliansari, W., Tobari, T., \& Houtman, H. (2020). Manajemen Peningkatan Mutu Peserta Didik [Management of Student Quality Improvement]. JMKSP (Jurnal Manajemen, Kepemimpinan, Dan Supervisi Pendidikan), 5(2), 175. https://doi.org/10.31851/jmksp.v5i2.3765

Kholipah, S., Maryatun, \& Pritandhari, M. (2020). Pengembangan Media Pembelajaran Ular Tangga Pada Mata Pelajaran Ekonomi Kelas X SMA Muhammadiyah 1 Metro Tahun Pelajaran 2017/2018 [Development of Snakes and Ladders Learning Media 
in Economics Subject Class X Muhammadiyah 1 Metro School Year 2017/2018]. Edunomia: Jurnal Ilmiah Pendidikan Ekonomi, 1(1), 60-71.

Liana, Y. R., Ellianawati, \& Hardyanto, W. (2019). Pengembangan E-Modul Interaktif Berbasis Android Menggunakan Sigil Software pada Materi Listrik Dinamis [Android-Based Interactive E-Module Development Using Sigil Software on Dynamic Electrical Materials]. Seminar Nasional Pascasarjana Universitas Negeri Semarang, 926-932.

Mi, D. I., Ii, A., \& Paiton, G. (2021). Implementasi Aplikasi Edmodo Sebagai Efektivitas Pembelajaran Al-Quran Hadits Pada Masa Pandemi Covid-19 [Implementation of the Edmodo Application as the Effectiveness of Learning Al-Quran Hadith During the Covid-19 Pandemic]. 5(1), 49-59.

Moore, K., Jones, C., \& Frazier, R. S. (2017). Engineering Education For Generation Z. American Journal of Engineering Education (AJEE), 8(2), 111-126. https://doi.org/10.19030/ajee.v8i2.10067

Ompusunggu, H. E. S. (2020). Hubungan Antara Motivasi Belajar Dengan Prestasi Belajar Mahasiswa/i Fakultas Kedokteran Universitas HKBP Nommensen [The Relationship Between Learning Motivation and Student Achievement, Faculty of Medicine, University of HKBP Nommensen]. Nommensen Journal of Medicine, 6(1), 32-35. https://doi.org/10.36655/njm.v6i1.247

Primasari, D. A. G., Maryani, S., Suparmanto., \& Juwita, D. (2019). Pemanfaatan TIK dalam Menumbuhkan Karakter Religius Peserta Didik Sekolah Dasar Di Gelumbang [Utilization of ICT in Growing the Religious Character of Elementary School Students in Gelumbang]. JMKSP (Jurnal Manajemen, Kepemimpinan, dan Supervisi Pendidikan) P-ISSN: 2548-7094 E-ISSN 2614-8021. 4(2).

Reflianto, \& Syamsuar. (2018). Pendidikan dan Tantangan Pembelajaran Berbasis Teknologi Informasi di Era Revolusi Industri 4.0 [Information Technology-Based Education and Learning Challenges in the 4.0 Industrial Revolution Era]. Jurnal Ilmiah Teknologi Pendidikan, 6(2), 1-13.

Rymarczyk, J. (2020). Technologies, opportunities and challenges of the industrial revolution 4.0: Theoretical considerations. Entrepreneurial Business and Economics Review, 8(1), 185-198. https://doi.org/10.15678/EBER.2020.080110

Sari, O. B. mila, Risdianto, E., \& Sutarno, S. (2020). Analisis Kebutuhan Pengembangan LKPD Berbasis Poe Berbantuan Augmented Reality untuk Melatihkan Keterampilan Proses Dasar pada Konsep Fluida Statis [Need Analysis of Augmented Reality-Assisted Poe-Based Student Worksheet Development to Practice Basic Process Skills on the Concept of Static Fluids]. PENDIPA Journal of Science Education, 4(2), 85-93. https://doi.org/10.33369/pendipa.4.2.85-93

Sen, A., Kapila, R., Chaudhary, S., \& Nigam, A. (2021). Biotechnological Applications of Microbial Enzymes to Replace Chemicals in the Textile Industry-A Review. TEXTILE Association, 82(2), 68-73. 
Sethy, S. S. (2012). Cognitive skills: A Modest Way of Learning through Technology. Turkish Online Journal of Distance Education, 13(3), 260-274.

Shahroom, A. A., \& Hussin, N. (2018). Industrial Revolution 4.0 and Education. International Journal of Academic Research in Business and Social Sciences, 8(9), 314-319. https://doi.org/10.6007/ijarbss/v8-i9/4593

Sinaga, S. (2020). Pengaruh Motivasi Dan Pengalaman Kerja Terhadap Produktivitas Kerja Karyawan Pada PT. Trikarya Cemerlang Medan [The Effect of Motivation and Work Experience on Employee Work Productivity at PT. Medan Cemerlang Trikarya]. Jurnal Ilmiah METADATA, 2(2), 159-169. https://doi.org/10.47652/metadata.v2i2.28

Utami, W. T., \& Yuwaningsih, D. A. (2020). Analisis Kebutuhan Pengembangan EModul Pada Pokok Bahasan Turunan Menggunakan Kvisoft Flipbook Maker Pro Untuk Siswa Sma Kelas XI [Analysis of E-Module Development Needs on Derivative Subjects Using Kvisoft Flipbook Maker Pro for Class XI High School Students]. Prosiding Seminar Nasional Konferensi Ilmiah Pendidikan, 1(1), 158160.

Verawati, V., Harapan, E., \& Fitria, H. (2020). Pengembangan Modul Anti Narkoba [Development of Anti-Drug Module]. JMKSP (Jurnal Manajemen, Kepemimpinan, Dan Supervisi Pendidikan), 6(1). https://doi.org/10.31851/jmksp.v6i1.3962

Wening, M. H., \& Santosa, A. B. (2020). Strategi Kepemimpinan Kepala Sekolah Dalam Menghadapi Era Digital 4.0 [Principal's Leadership Strategy in Facing the Digital Age 4.0]. JMKSP (Jurnal Manajemen, Kepemimpinan, Dan Supervisi Pendidikan), 5(1), 56. https://doi.org/10.31851/jmksp.v5i1.3537

Widiyatun, F., Sumarni, R. A., \& Kumala, S. A. (2020). Pengembangan dan Validasi Kartu Domino Besan (Besaran dan Satuan) [Domino Besan Card Development and Validation (Amount and Units)]. Prosiding Seminar Nasional Sains, 1(1), 58-64.

Winaryati, E., \& Munsarif, M. (2021). $R \&$ \& Literature Review for Development of a Digital Platform for the Learning Supervision Evaluation Model (MESp). 9(2), 181192.

Zainul, Adha., Gusnaedi., Letmi, D. (2018). Pembuatan Bahan Ajar Fisika Berorientasi Model Pembelajaran Kemampuan Berpikir Kritis Pada Materi Pengukuran dan Vektor Staf Pengajar Jurusan Fisika [Making Physics Teaching Materials Oriented Learning Models of Critical Thinking Ability on Measurement and Vector Materials for Physics Department Teaching Staff]. FMIPA Universitas Negeri Padang. 11(1), 137-144. 